\title{
Editors' introduction to Keeping cultures alive: Archives and Indigenous human rights
}

\author{
Sue McKemmish • Livia Iacovino • Lynette Russell • \\ Melissa Castan
}

Published online: 19 February 2012

(C) Springer Science+Business Media B.V. 2012

\begin{abstract}
Keeping Cultures Alive investigates the relationship between Indigenous human rights and the archives through an interdisciplinary and comparative lens, bringing together papers by Indigenous and non-Indigenous experts in Indigenous studies, human rights, law and archival science. It explores Indigenous human rights in an international context with particular reference to the implications of the international human rights agenda for current and future archival practice in Australia, Canada, New Zealand and the United States.
\end{abstract}

Keywords Indigenous human rights · Cultural rights ·

Archival self-determination · Indigenous archives · Participatory archives

\section{S. McKemmish ( $($ )}

Director of the Centre for Organisational and Social Informatics, Monash University,

Caulfield, VIC 3145, Australia

e-mail: Sue.McKemmish@monash.edu

L. Iacovino

Centre for Organisational and Social Informatics, Monash University,

Caulfield, VIC 3145, Australia

e-mail: Livia.Iacovino@monash.edu

L. Russell

Monash Indigenous Centre, Monash University, Clayton, VIC 3800, Australia

e-mail: lynette.russell@monash.edu

M. Castan

Castan Centre for Human Rights Law, Faculty of Law, Monash University,

Clayton, VIC 3800, Australia

e-mail: melissa.castan@monash.edu 


\section{Introduction}

There is a gathering momentum in Indigenous human rights globally and locally following the UN Declaration on the Rights of Indigenous Peoples (UN 2007). Most significantly for the archival community worldwide, the Declaration recognises the inherent individual and collective rights of Indigenous peoples to preserve their identity and culture while participating to the fullest extent in mainstream culture. Rights of self-determination and the principles of non-discrimination and free, prior, informed consent provide the foundation for the exercise of cultural rights as human rights. The title of this special issue focuses attention on the role that archives can play in supporting Indigenous human rights and keeping Indigenous cultures alive. In this context, it is imperative for archivists to become more aware of the Indigenous human rights agenda and to ensure that archival principles and practices address the archival dimensions of that agenda.

The editors occupy a variety of academic and identity spaces, but all of us, Indigenous and Settler, have extensive experience in working with archives as researchers, educators, policy makers, practitioners and community advisors. In this special issue, we bring together papers at the nexus of Indigenous human rights, the law and archival science. The papers are based on and extend presentations and discussion at a workshop held in Melbourne, Australia, in October 2010 as part of the Australian Society of Archives Annual Conference (Monash University and National Archives of Australia 2010). Our aim is to contribute to raising awareness of archives-related Indigenous human rights issues in Indigenous, human rights, legal and archival communities and to highlight the need for these communities to work in partnership together to address these issues. Our hope is that this special issue of Archival Science will support the development of action agendas around the world that embed Indigenous human rights into the professional responsibilities, culture and practices of archival and records communities. To this end, in the Appendix to the Editors' Introduction, we include a Position Statement on Archives and Indigenous Human Rights in Australia. It was initially developed by Dr Livia Iacovino and Professor Eric Ketelaar for the Trust and Technology Project, a research partnership involving the Public Record Office of Victoria, the Koorie Heritage Trust Inc, the Victorian Koorie Records Taskforce, the Indigenous Issues Special Interest Group of the Australian Society of Archivists, Koorie communities throughout Victoria, and Monash University (Monash University et al. 2009; McKemmish et al. 2011). The statement was revised following the Archives and Indigenous Human Rights Workshop and in the context of Indigenous human rights developments internationally, and in Australia, Canada, New Zealand and the United States as explored by the papers in this special issue. The Statement proposes an Archival Indigenous Human Rights Action Agenda for consideration by archival and Indigenous communities in Australia. The Statement's exposition of the relationship between Indigenous human rights and the archives, together with the strategies it proposes, may also be of relevance, or even agenda-setting, elsewhere.

Reflecting their complex colonial and post-colonial pasts and presents as settler nations, which dispossessed their Indigenous peoples, Australia, Canada, New 
Zealand and the United States initially opposed the 2007 UN Declaration on the Rights of Indigenous Peoples. These were the only four countries in the General Assembly who were not signatories to the Declaration, although all have belatedly endorsed it. The archives within colonial and post-colonial societies have been implicated in the continued oppression of Indigenous people. As in other circumstances where oppressive regimes have existed, archives in these societies have historically been agents of human rights abuse and collusion. Today, they can play a critical role in the recovery of Indigenous knowledge and language. They provide evidence for re-establishing familial heritage, enabling family link-ups, supporting community regeneration, pursuing land claims and seeking redress relating to dispossession and human rights abuse. Archives in the present and future can support rights to language, culture, cultural and spiritual identity, and relationships with country. They provide a critical underpinning for Indigenous human rights, self-determination and the exercise of cultural rights as human rights.

Acknowledgement by the archival and records community of Indigenous rights of self-determination and facilitation of the exercise of cultural rights as human rights involves moving beyond the current focus on individual access rights to involve Indigenous individuals and communities in decisions about appraisal, access and management of records relating to them, including non-Indigenous archival sources of Indigenous knowledge. Free, prior and informed consent, which is an essential component of self-determination, means that Indigenous peoples need to be involved in the design, development, implementation, monitoring and evaluation of all programs, policies and legislation that affect them, including archives and Indigenous human rights initiatives themselves. Supporting the related right to know and enabling the right of reply involve archival institutions disclosing to Indigenous people and communities that they hold records relating to them, and developing systems to allow Indigenous people to add their perspectives and stories to 'set the official record straight'.

Jane Anderson, an expert in Indigenous law, has pointed to the paradigm shift involved in positioning 'Indigenous peoples' rights to control, use and derive benefit from Indigenous knowledge as fundamental human rights'. With colleague Kate Bowrey, Anderson explored how problematic Western intellectual property frameworks, and the counterbalancing push towards 'open-knowledge communities, the public domain and public policies protecting the global sharing of information', can be for 'Indigenous peoples struggling to regain control over knowledge resources today', given that 'historically, dispossession of Indigenous persons in settler communities was concomitant with their exclusion from "the public", (Bowrey and Anderson 2009, Abstract). Taking the case of the secret and sacred nature of some Indigenous cultural practices and knowledge as an example, they point to how intellectual property and the public domain sit uncomfortably with recognition of the right to maintain the secrecy of Indigenous cultural practices and knowledge as an important cultural right in Article 13 of the 2007 Declaration on the Rights of Indigenous Peoples. Anderson points to the implications for control over Indigenous knowledge of the shift from a Western intellectual property and public domain discourse to an Indigenous human rights discourse: 
A human rights approach allows Indigenous peoples' rights in knowledge control to be considered as one part of a larger rights framework in which indigenous peoples are already actively participating (Anderson 2010 p. 35).

The far-reaching implications of this shift for archival law, policies and practices are explored in the papers in Keeping Cultures Alive.

In 'Indigenous human rights and knowledge in archives, museums and libraries: Some international perspectives with specific reference to New Zealand and Canada', international human rights law expert Professor Brad Morse gives an historical overview of the recognition of Indigenous human rights in the international legal context. Morse provides a detailed analysis of the 2007 UN Declaration of Indigenous Rights with a particular focus on the rights of selfdetermination linked to the rights of Indigenous peoples to practice and develop culture, tradition and ceremony. He connects the international legal developments in this area with 'the concrete concerns of Indigenous peoples to implement their inherent right of self-determination as peoples and to press the state to live up to its responsibility', and to assert human rights in Indigenous knowledge in archival records. Using comparative case studies drawn from Canadian First Nation and Maori experience, Morse discusses constitutional, legal and policy reforms, linked to treaty obligations that reflect changing approaches to dealing with Indigenous knowledge and culture. He also points to the challenges they pose to national and state archives, libraries and museums, and the ways in which these institutions have responded so far. He discusses how principles of cultural guardianship associated with the Maori concept of Kaitiakitanga ('the protection and preservation of the taonga [gifts] of our ancestors for future generations') are being embedded in the practices of Te Papa Tongarewa, the National Museum of New Zealand, suggesting that this approach might provide a useful model for other institutions and nations. Morse concludes that the Canadian and New Zealand experience demonstrate that moving towards 'a more cooperative, partnership-based approach has been difficult for museums, libraries and archives in settler states', but that positive changes are occurring in the context of evolving relationships between Indigenous and nonIndigenous peoples and changing public attitudes. He urges archivists, librarians and museum curators to harness the power of the language of the 2007 UN Declaration to the work of transforming their institutions in the societies in which Indigenous and Settler people live.

In his paper, 'The practical power of human rights: How international human rights standards can inform archival and record keeping practices', the Australian Aboriginal and Torres Strait Islander Social Justice Commissioner, Mick Gooda, addresses the Indigenous human rights agenda in Australia in the context of international developments. He believes that the 2007 UN Declaration on the Rights of Indigenous Peoples is a blueprint for action by Indigenous peoples, governments and other third parties, centred on respect for the rights and roles of Indigenous peoples within society, and essential to the survival, dignity and well-being of Indigenous peoples all over the world. Gooda sees the driving principles of the UN Declaration as self-determination, good faith and participation in decision-making. Referring to how Indigenous people 'have been intensively observed, recorded, 
measured and categorised since colonisation', he reminds us that the laws and practices that protect these records, including archival laws and intellectual property regimes, are embedded in Western thought and legal traditions: 'This has impeded our peoples' ready access to these records and repositories of culture and denied our structures of ownership, control and regulation.' Gooda outlines how the principles of the Declaration can and should influence archival and recordkeeping practices. Invoking the 'practical power of human rights', he encourages Aboriginal and Torres Strait Islander peoples to exercise their rights to free, prior and informed consent, and to participate in decision-making to ensure that archival and recordkeeping processes respect and accommodate Indigenous 'voices, aspirations, cultures and their value and knowledge systems'. He places the onus on archiving and recordkeeping institutions to evolve in order to accommodate Indigenous peoples, rather than expecting Indigenous peoples to conform to mainstream practices. In conclusion, Gooda states that it is incumbent upon governments and others, including archivists and recordkeepers, to support the move by Indigenous peoples 'from passive and powerless subjects, to active participatory agents'. His paper is a rallying call for a resetting of relationships between archival and Indigenous communities, and the development of partnerships between Indigenous and archival communities, built on dialogue, education, exchange of knowledge, recognition of and respect for different ways of knowing, and processes for working through things together in negotiated spaces.

Continuing the international focus and its relevance to the Australian context, Australian Indigenous lawyer Terri Janke and archival scholar Livia Iacovino explore the relevance of the international human rights framework to Indigenous ownership and control of cultural and intellectual property rights and the implications for archival institutions. In 'Keeping cultures alive: Archives and Indigenous cultural and intellectual property rights', they trace the history of the struggle for Indigenous cultural and intellectual property rights in Australia from the landmark 1998 Australian report Our culture: Our future (Janke 1998a) to the 2007 UN Declaration on the Rights of Indigenous People. Janke and Iacovino highlight the difficulties of recognising traditional custodians of Indigenous knowledge within existing copyright law in a number of landmark Australian legal cases and discuss more recent rights-based initiatives in archival organisations and museums. They discuss the archival and legal controversies that have arisen from attempts to counterbalance intellectual property law with Indigenous understandings of knowledge, and structures of ownership, control and regulation. Janke and Iacovino also consider the problematic term 'Traditional Cultural Expressions' (TCE), a copyright concept established by the World Intellectual Property Organisation (WIPO). The WIPO approach creates an 'exception' for Indigenous intellectual property rights in traditional knowledge (Anderson 2010; Bowrey and Anderson 2009), whereas in the UN Declaration, cultural rights are treated as core human rights. A narrow interpretation of the TCE concept of traditional knowledge may exclude many archival sources of Indigenous knowledge and culture. Janke and Iacovino propose that archivists and records managers grappling with the implementation of Indigenous rights in traditional knowledge in the archives use a human rights framework to resolve conflicts that arise in trying to balance traditional Indigenous 
cultural interests with mainstream archiving traditions and the open use of knowledge. In conclusion, they highlight the important current and future role of Australian archivists and archival organisations in supporting Indigenous human rights and keeping Indigenous cultures alive through processes in which Indigenous Australians are active participants in the overall management of records created by or about them, in particular in cases where they are not considered by Australia's Western legal frameworks to be the legal 'owners' or 'authors' of the records that contain their knowledge.

Allison Boucher Krebs, a member of the Sault Ste Marie Tribe of Chippewa Indians, brings a Native American perspective to the issue of Indigenous knowledge rights. In 'Native America's $21^{\text {st }}$ century right to know', she explores recent initiatives in the archives, library and museum fields, reflecting on the three decades that have passed since the doyen of Native American studies and rights activism, Vine Deloria Jr., issued a broadside to archives, libraries and other collecting institutions. Deloria argued that Native Americans had 'The Right to Know' about their past(s) and what relevant materials these institutions held. Furthermore, Deloria asserted that these rights were enshrined within the United States federal government's treaty responsibilities. Deloria's calls for the establishment and funding of tribal libraries and archival services resulted in numerous examples with varying successes. Krebs examines two initiatives relating to this Indigenous 'right to know', funded-at least partially-by the US Federal government. The first of these case studies relates to the Institute of Museum and Library Services' grants to Indian tribes, and the second example comes from an analysis of the Fourth Museum of the National Museum of the American Indian. Krebs places these initiatives within the broader Indigenous knowledge ecology and argues that it is Indigenous museums, libraries and archives, their founders, administrators, staff and communities who will set the agenda. Krebs looks to a future in which communitydriven, controlled and supported libraries, archives and museums will be reciprocally altered and reformed in meaningful and profound ways.

In their paper, 'Local archives and community collecting in the digital age', Lyndon Ormond-Parker and Robyn Sloggett also focus on the importance of community-driven and controlled initiatives, using examples drawn from local Australian Indigenous community collecting and archiving projects. Against the background of the multitude of technological offerings that have emerged in the digital era, Ormond-Parker and Sloggett demonstrate how Aboriginal communities in Australia have taken a range of new information technologies in innovative and at times surprising directions. They argue that these initiatives and the development of community-controlled archives require engagement with and policy responses from mainstream collecting institutions and governments, informed by the human rights agenda. In this framework, the opportunities presented by archiving and collecting activities in Aboriginal communities include potential economic empowerment; community empowerment and strengthening of group pride and identity through 'owning' the emergent histories, stories, images and other materials; and the potential for developing professional training and employment paths for young people. However, the recognition of these opportunities is tempered by an appreciation of the potential for serious threats to the protection, preservation, 
collection and use of this archival material. Such threats are both immediate and long term. As technology changes and formats alter, communities need to be capable of resourcing their responses, and preserving archives in remote locations and harsh environmental conditions. Unfortunately, there is often a lack of information technology expertise and archival knowledge which, when coupled with a lack of knowledge about or consensus on archival systems, standards and principles, may pose a serious risk to the longevity of the archives. Ormond-Parker and Sloggett suggest that optimising the long-term sustainability of archives held in Aboriginal communities should be conceived of as part of a nationally distributed collection with community-generated protocols and community-based management.

Melissa Castan and Julie Debeljak's article, 'Indigenous peoples' human rights and the Victorian charter: a framework for reorienting recordkeeping and archival practice', focuses on a case study of a local piece of human rights legislation, the Victorian Charter of Human Rights and Responsibilities Act 2006, and its implications for Indigenous human rights in that south-eastern Australian state. The Victorian Charter is particularly significant in the Australian context, as Australia has no treaty with its Indigenous people, no constitutional human rights and no federal human rights law. As human rights in the Charter are modelled on the International Covenant on Civil and Political Rights, Castan and Debeljak argue that it may present the best opportunity for Indigenous Australians in Victoria to participate in the management of records, in which they are the 'subjects', protect their narratives and culture and recover their knowledge. Their detailed legal analysis of the concepts of culture, heritage, traditional knowledge and cultural rights in the Charter, other Charter rights relating to privacy, family and reputation, and its requirement that international obligations be taken account of when developing, interpreting and applying Victorian law and policy demonstrates how the Charter could be used to enhance Indigenous human rights and Indigenous ownership of the knowledge in records. Castan and Debeljak emphasise that Indigenous persons are the rights bearers. A great strength of the Charter is that it places the onus on the public service and its organisations, including archives and records programs, to ensure that human rights are protected in line with the Charter and international law, including the rights of Indigenous people to give prior consent in situations that impact on their cultural rights. The legal arguments in Castan and Debejak's article supporting the protection and promotion of Indigenous culture in records set up powerful challenges for archivists, records managers and their organisations.

Emeritus Archivist of Canada, Ian Wilson, addresses the role of archives in Canadian human rights cases, including cases involving First Nations. His paper, " "Peace, order and good government": Archives in society', is a slightly reworked version of what was first presented at the Monash University 2010 Whyte Memorial Lecture delivered on the evening of the workshop on Archives and Indigenous Human Rights. The phrase 'peace, order and good government' refers to the relationship of the Crown and the citizen. Wilson argues that the archival record is fundamental to that relationship, 'providing its authoritative legal basis, documenting its evolution and continuing as a reminder of both our proudest achievements and our most dismal failures as a society'. Looking back on a long career as a 
provincial archivist, national archivist and librarian, and president of the International Council on Archives, Wilson presents a retrospective reflection on the potential power of the record to redress past wrongs and abuses, drawing on his experiences in cases in which the archives have underpinned social justice and human rights. He highlights both 'the strengths and the weaknesses of the record, the perception of archives as an agency of the state, and the role of archives in helping society address highly contentious issues'. Wilson ends with a clarion call for the international archival community to engage in a dialogue across time, space and cultures relating to the part the archives might play in documenting society in all its complexity and diversity.

In his paper, Mick Gooda challenges all of us, Indigenous and Settler, to 'harness the practical power of human rights', engaging Indigenous peoples as 'substantive and major stakeholders' in determining archival and recordkeeping frameworks, laws, polices and programs relevant to Indigenous culture, cultural property and knowledge systems. Allison Krebs, Lyndon Ormond-Parker and Robyn Sloggett look to a future in which community-driven and controlled archival programs will be sustained as part of nationally distributed collections with community-generated protocols and community-based management, with appropriate support from and engagement with governments, mainstream archival and recordkeeping institutions, and archival communities.

The papers in this special issue of Archival Science suggest a range of strategies to support the exercise of Indigenous cultural rights in records and archival selfdetermination, including partnerships between archival and Indigenous communities to develop coherent international and national frameworks for the active participation of Indigenous peoples in the governance and operation of archival services using the 2007 UN Declaration as a road map. These strategies include reform of archival law and policy to recognise individual and collective Indigenous cultural rights in records, including collective rights relating to access and privacy, and the extension of existing international and national laws and protocols relating to Indigenous human rights and heritage to archival sources of Indigenous knowledge. Appropriate resourcing of Indigenous archives and records programs in Indigenous and nonIndigenous archival institutions, and in Indigenous communities, is recognised as critical to their sustainability. In the absence of legal reforms, the papers also point to the possible use of a combination of policy initiatives, participatory archives models which re-position records subjects as records agents, and innovative information technology to extend the existing moral rights of Indigenous individuals and communities relating to the control, disclosure, access and use of records, for example, in the development of digital repatriation strategies and programs, and digital archives. Within archival science itself, an expansion of the definition of records creator to include everyone who has contributed to a record's creative process and has been affected by its action could support the enforcement of a broader spectrum of rights and obligations. Keeping Cultures Alive envisions a future in which, globally and locally, Indigenous, human rights and archival communities work together to embed Indigenous human rights in archival law, policy, culture and practice. 


\section{Appendix to Editors' introduction: Position Statement on Archives and Indigenous Human Rights in Australia}

The Position Statement on Archives and Indigenous Human Rights in Australia was originally prepared on behalf of the Trust and Technology Project (Monash 2009) by Dr Livia Iacovino, Professor Eric Ketelaar and Professor Sue McKemmish, and is based on extensive research of relevant human rights instruments undertaken by Dr Iacovino and funded by the Jean Whyte Bequest (Iacovino 2010). The Australian Research Council Linkage Project, Trust and Technology: Building an Archival System for Indigenous Oral Memory, which brought together about one hundred Koorie and other Indigenous Australian people along with researchers from the Public Record Office Victoria, the Koorie Heritage Trust Inc, the Victorian Koorie Records Taskforce, the Indigenous Issues Special Interest Group of the Australian Society of Archivists, and Monash University's Centre for Organisational and Social Informatics and Centre of Australian Indigenous Studies.

The Statement has been revised in the light of the presentations and discussions at a Workshop at the 2010 Australian Society of Archivists Conference in Melbourne, Archives and Indigenous Human Rights: Towards an understanding of the archival and recordkeeping implications of Australian and international human rights for Indigenous Australians, sponsored by Monash University and the National Archives of Australia. The invaluable contribution of speakers and participants is acknowledged.

\section{Preamble}

We do this in the spirit of resetting the relationship between Indigenous and non-Indigenous Australians and building trust ... The Declaration gives us new impetus to work together in trust and good faith to advance human rights... (Australian Minister for Indigenous Affairs, Jenny Macklin, announcing Australia's change of position on the Declaration on 3 April 2009, as quoted in the Australian Human Rights Commission guide: AHRC 2010, p. 12)

At its core the Declaration is based on the principles of self-determination, good faith and participation in decision-making... [W]e need to harness the practical power of human rights. In exercising our right to participate in decision-making, Aboriginal and Torres Strait Islander peoples can demonstrate this practical power. It is critical that Aboriginal and Torres Strait Islander peoples are substantive and major stakeholders in determining appropriate archival and recordkeeping processes for Indigenous culture, cultural property and knowledge systems (Aboriginal and Torres Strait Islander Social Justice Commissioner Mick Gooda speaking at the Archives and Indigenous Human Rights Workshop, Australian Society of Archivists Conference, 12 October 2010).

The Australian Government has committed to resetting the relationship with our peoples. Active participation in decision-making that affects our peoples is a key part of resetting the relationship. In practice, our participation in decision-making is limited. To meet human rights standards we should be 
involved in all major decisions affecting us, including on issues around land, development, culture, housing, health, education, employment, child welfare, social services and criminal justice (AHRC 2010, p. 40).

Archives can support human rights but have in the past been instruments of human rights abuse and oppressive regimes. Today they can, and indeed do, play a critical role in the recovery of Indigenous knowledge and language and provide evidence for establishing identity, family link-ups, community regeneration, land claims and redress of human rights abuse. Archives can thereby underpin Indigenous human rights, self-determination and the exercise of cultural rights as human rights. They can support rights to language, culture, cultural and spiritual identity (AHRC 2010, Part 6 ), rights to and relationships with country, and the dissemination of information which 'reflects the dignity and diversity of Aboriginal and Torres Strait Islander peoples' cultures, histories, experiences, and hopes' (AHRC 2010, p. 36).

A major obstacle to the implementation of Indigenous human rights in archives in Australia has been that Australian legal and archival frameworks have not addressed archives-related Indigenous human rights issues or provided for the exercise of cultural rights in records for Indigenous peoples who are considered to be the subjects of records. Archivists and records managers are often unaware of the individual and collective archives and records-related rights, which are essential to Indigenous self-determination, preservation of culture and identity as recognised in the UN Declaration on the Rights of Indigenous Peoples 2007.

The gathering momentum in the field of human rights-locally and internationallymakes it imperative for archival and related professions to become aware of the relevance of the human rights agenda to their work. Policies and practices in archival institutions in Australia are currently not fully in line with international conventions relating to Indigenous human rights. Acknowledgement by archival institutions of Indigenous rights of self-determination and facilitation of the exercise of cultural rights as human rights, linked to the principle of non-discrimination, involves moving beyond the current focus on individual access rights to involve individuals and communities in decisions about appraisal, access and management of records relating to them, including non-Indigenous archival sources of Indigenous knowledge. Free, prior and informed consent, which is an essential component of self-determination, means that Aboriginal and Torres Strait Islander peoples need to be involved in the design, development, implementation, monitoring and evaluation of all programs, policies and legislation that affects them, including archives and Indigenous human rights initiatives themselves. Supporting the related right to know and enabling the right of reply involve archival institutions disclosing to Indigenous people and communities that they hold records relating to them, and developing systems to allow Indigenous people to add their perspectives and stories to 'set the official record straight'.

\section{Foundation rights of self-determination and equality}

The foundational rights embodied in the UN Declaration are the right of selfdetermination and the right to be treated equally (AHRC 2010, Part 3). Indigenous 
participation linked to self-determination lies at the heart of human rights. Self-determination is defined as the right of peoples to a system that respects and facilitates their political, social, economic and cultural participation and development as specified in the International Covenant on Civil and Political Rights (UN 1966a) and the International Covenant on Economic, Social and Cultural Rights (UN 1966b). The principle of free, prior and informed consent is an integral part of self-determination.

Around Australia archival institutions have begun to build long-term trusted relationships with Indigenous communities as users of archival services. Providing better access to archival and records collections for Aboriginal and Torres Strait Islander peoples has been a major focus, for example, the Bringing Them Home Index developed by the National Archives of Australia and Public Record Office of Victoria. The 2007 UN Declaration provides a framework for extending and resetting existing relationships between Indigenous peoples, archival institutions and the archival profession based on equal partnership, building trust and mutual respect through participatory rather than consultative models.

Active participation in the design, development, implementation, monitoring and evaluation of archival laws, policies and programs is a crucial aspect of building new archival relationships in line with the recommendations of the Australian Human Rights Commission (AHRC 2010, p.41). It is based on the principle of free, prior, informed consent rather than consultation. Archival law, policy and program reforms, based on respecting Indigenous knowledge systems, can provide frameworks and guidelines for the exercise of Indigenous cultural rights in records and archives compliant with the Declaration.

Full realisation by Indigenous peoples of their human rights, including the exercise of cultural rights, also requires eliminating racism:

to promote full and equal enjoyment of civil, political, economic, social and cultural rights, as well as the benefits of sustainable development, while fully respecting their distinctive characteristics and their own initiatives (Calma 2009).

\section{Related archival action agenda: resetting relationships}

- Establish partnerships between the Australian archival community and Indigenous communities to develop coherent national frameworks for the active participation of Indigenous peoples in the governance and operation of archival services using the 2007 UN Declaration of the Rights of Indigenous Peoples and the Australian Human Rights Commission Guide as 'road maps'

- Reform Australian archival law and policy to recognise Indigenous cultural rights in records, including individual and collective rights, and consequent extension of existing international and national laws and protocols relating to Indigenous human rights and heritage to archival sources of Indigenous knowledge

- Review existing archival laws, policies and programs to ensure compliance with the UN Declaration and any relevant federal, state and territory Indigenous human rights frameworks and laws 
- Review Australian Society of Archivists' endorsed statements of professional ethics, and archival values to ensure compliance with the UN Declaration

- Review and revise, using the language of human rights, the outdated Australian Society of Archivists Policy statement on archival services and Aboriginal and Torres Strait Islander peoples (ASA 1996), and the ATSI Library and Information Resources Network Protocols, updated version of 1995 ATSI Protocols for Libraries, Archives and Information Services (ATSILIRN 2005), with reference to best practice protocols such as the Native American Protocols (First Archivists Circle 2007), and protocols issued by AIATSIS (2010), the State Library of South Australia (2010), State Records NSW (2008), the National and State Libraries of Australasia (2007) and the Australian Heritage Commission (2002) ${ }^{1}$

- Diversify the archival profession to achieve appropriate representation of Indigenous peoples.

\section{Rights of indigenous peoples as a collective}

Human rights standards were developed from non-Indigenous thinking and have historically focused on the individual. For example an individual has the right to own property. Indigenous peoples often organise societies as a group (i.e. clan, nation, family or community) and individual rights are not always suitable. The Declaration confirms that we have group or collective rights. For example, it acknowledges that we have the right to own country and hold cultural knowledge as a group, and the right to determine what that group looks like (AHRC 2010, p. 20).

The 2007 UN Declaration establishes the right of Indigenous peoples as a collective or as individuals to the full enjoyment of all human rights and fundamental freedoms as recognised in the Charter of the United Nations, the Universal Declaration of Human Rights (UN 1948) and international human rights law. However, critically relevant intellectual property, freedom of information, privacy and archival laws in Australia are cast in the language of individual not communal rights. The general effect of these laws is that the organisations that create or receive and maintain records relating to Indigenous peoples exercise almost all control over them. In relation to government records, privacy, freedom of information and public records laws give records subjects some rights over the collection, use and disclosure of information about themselves. However, these rights apply only to individual records subjects: they cannot be exercised by

\footnotetext{
1 The statement reads: "The ASA endorses the principles and guidelines set out in the Aboriginal and Torres Strait Islander Protocols for Libraries, Archives and Information Services which were developed by the Aboriginal and Torres Strait Islander Library and Information Resource Network and published in 1995. ASA members are encouraged to become familiar with these Protocols and to support their implementation in the archives in which they are employed." The 1995 Aboriginal and Torres Strait Islander Protocols for Libraries, Archives and Information Services were updated in 2005 (ATSILIRN 2005), but the ASA was not involved and has not endorsed the updated version.
} 
Indigenous peoples as a collective or by individuals in relation to deceased family members (Iacovino 2010).

\section{Related archival action agenda: collective rights}

- Take into account on an ongoing basis the rights of Indigenous peoples and communities as a collective in the development and reform of archival laws, policies and programs

- Recognise the moral rights of the collective author in archival documentation

- Recognise collective rights relating to access and privacy and develop strategies for their realisation.

\section{Free, prior and informed consent}

The standard of free, prior and informed consent is to be met before any of the following actions are taken:

- projects or decisions that affect our country including mining, development and the use of sacred sites

- the use of biological materials, traditional medicines and knowledge, including:

- artwork, dance and song

- making agreements or treaties between government and our peoples

- the creation of laws or policies that affect our peoples

- actions that could lead to the forced removal of our children or from country (AHRC 2010, p. 25)

The Australian Human Rights Commission Guide recommends that governments and other organisations should negotiate with relevant Indigenous organisations, communities and individuals when making policies, laws or undertaking activities that affect them with the aim of obtaining consent. It emphasises that this is a much stronger obligation than merely providing information or consulting. It involves an honest and open process of negotiation between parties on an equal footing and reaching a solution or agreement acceptable to all. A major issue for archival institutions and programs with respect to the principle of free, prior, informed consent is that of its possible retrospective application to archival records relating to Indigenous communities, which have been accumulated and managed in the past without such consent.

\section{Related archival action agenda: free, prior, informed consent}

- Negotiate with relevant Indigenous organisations, communities and individuals when making policies, laws or undertaking activities that affect them with the aim of obtaining free, prior and informed consent 
- Investigate with relevant Indigenous organisations, communities and individuals the retrospective application of the principle of free, prior, informed consent to past archival actions.

\section{Self-determination, non-discrimination and the exercise of cultural rights as human rights}

Under Australian law, our cultural heritage and traditional knowledge are partly protected by various legal regimes including intellectual property, native title, cultural heritage and environmental laws. These regimes try to fit our systems of knowledge and understanding into Western legal concepts. This results in a partial and inadequate protection of our cultural heritage and traditional knowledge.

We can lobby governments to work with us to develop a legal framework that adequately protects our heritage and knowledge. These laws should protect and control the use of our heritage and knowledge and be consistent with the principle of free, prior and informed consent (AHRC 2010, p. 50).

We have the right to revitalise, use, develop and pass on to future generations our ways of being and knowing. This includes:

- our histories and our oral traditions

- our languages and ways of communicating

- our ways of thinking about the world

- our names for communities, people and places (AHRC 2010, p. 33).

In relation to identity, culture, language and relationship with country, the principle of self-determination supports the rights of Indigenous peoples to their distinctive identities, and to identify themselves as Indigenous, as well as rights and duties to maintain and develop their own cultures and knowledge systems. It includes the right to be recognised as the primary guardians and interpreters of their cultures, and to exercise their cultural rights as human rights. Protecting Indigenous cultural and intellectual property is based on the principle of self-determination (Janke 1998b).

Specifically, in respect to the exercise of individual and collective cultural rights, Article 31 of the 2007 UN Declaration states:

Indigenous peoples have the right to maintain, control, protect and develop their cultural heritage, traditional knowledge and traditional cultural expressions, as well as the manifestations of their sciences, technologies and cultures, including human and genetic resources, seeds, medicines, knowledge of the properties of fauna and flora, oral traditions, literatures, designs, sports and traditional games and visual and performing arts. They also have the right to maintain, control, protect and develop their intellectual property over such cultural heritage, traditional knowledge, and traditional cultural expressions.

With respect to Indigenous peoples, the principle of non-discrimination, as supported by the UN Declaration (UN 2007), the Convention on the Elimination of 
Racial Discrimination (UN 1965), the Australian Racial Discrimination Act 1975 and state anti-discrimination law highlights the need for nations to ensure that Indigenous communities can exercise their rights to practise and revitalise their cultural traditions and customs, and to preserve and to practise their languages, based on recognition of and respect for the distinct cultures, histories, languages and ways of life of Indigenous peoples as an enrichment of a nation's cultural identity.

\section{Related archival action agenda: self-determination, non-discrimination and the exercise of cultural rights}

- Support and appropriately resource archives as vital sources of information and knowledge, including knowledge of identity, culture, language and relationships with country, which underpin the right to identify as Indigenous, related rights to distinctive identities, cultures and knowledge systems, and 'the right to revitalise, use, develop and pass on to future generations... ways of being and knowing' (AHRC 2010, p. 33)

- Engage, on an ongoing basis, Indigenous communities in the capture, appraisal, management, preservation and access to records that contribute to their selfdetermination and cultural identity

- Australian archival institutions and records authorities to use a combination of information technology, legal and policy initiatives to extend the existing legal and moral rights of Indigenous individuals and communities relating to the control, disclosure, access and use of records, for example, in the development of digital repatriation strategies and programs, and digital archives

- Negotiate rights by creating a register of interested persons (descendants of the relevant community) for ongoing management of relevant sets of records.

- Recognise and implement the right of Indigenous communities and individuals to determine third party access to records held by archival organisations on the basis of redressing discrimination

- Under the Victorian Charter of Human Rights and Responsibilities Act 2006 review and revise the Public Records Act (VIC) and the policies and actions of the Office in terms of compatibility with the Charter and international conventions to ensure special provisions for Indigenous Victorian communities.

\section{The right to know the truth and the right of reply}

The United Nations Commission on Human Rights (UNHRC 1997 \& 2005) adopted the Joinet-Orentlicher Principles to guide member states in dealing with human rights violations. They deal amongst other things with the inalienable individual and collective right of individuals and communities to know the truth about past events, the duty of the state to preserve and make accessible archives of repression and abuse as part of the collective memory, and the entitlement of individuals to know that there is a record about them, and to challenge its validity by exercising a right of reply. 


\section{Related archival action agenda: right to know and right of reply}

- Identify Indigenous communities or individuals in records, contact them via appropriate representative bodies

- Disclose that there are records relating to them

- Develop procedures to enable them to exercise a right of reply - that is, to set the record straight; make comments upon the inaccuracies or limitations of institutional records, to contribute family narratives, which expand upon or give context to institutional records and to present alternative versions of events. An example would be a system that enabled use of annotations as a right of reply, and the extension of this right to descendants, which also enabled annotators to retain ownership of the annotations.

\section{Social media and human rights}

Digital technologies, participatory models and postmodern concepts like co-creatorship and records as social entities have the potential to support the 'decolonisation' of the archive, and the exercise of cultural rights in archives as human rights, repositioning Indigenous peoples who have hitherto been the 'captives of the archives' (Fourmile 1989), the subjects of records, and the objects of the archival gaze as active participatory agents in archival and recordkeeping program and system design and implementation.

Emerging research and theory building in archival science have cleared the way for a refiguration of recordkeeping structures and values, and subsequently for developing, testing and implementing methods and tools for new recordkeeping and archival policies and practices which accord to modern societal needs and expectations. This may be summarised by citing Tom Nesmith's formulation of the new concept of provenance of a record: 'The social and technical processes of the records' inscription, transmission, contextualization, and interpretation which account for its existence, characteristics, and continuing history' (Nesmith 1999, p. 146; see also Douglas 2010).

The paradigm shift in archival theory, methodology and practice is to a large extent due to new technologies and their adoption and adaptation in society. Social software, including annotation systems, wikis, blogs, social networks, social recommender systems and a host of other Web 2.0-based applications are drastically changing cultural practices of record creation and recordkeeping. Government 2.0 implies that records are created in an interactive dialogue between the government organisation and the citizen, requiring the customer or citizen to become a party to the business function, which created the record, a co-creator. In our digital world interactive and hyperlinked: 'Texts become "hypertexts" which are reconstructed in the act of reading, rendering the reader an author' (Poster 2001, p. 188).

This social and cultural phenomenon of co-creatorship entails a shift of the traditional paradigm that locates the agency of a record solely in its author. This is not to say that records subjects participating in the creation of records should be given ownership rights: there are other ways by which archival policies and 
practices in a Government 2.0 environment can accommodate the phenomenon of co-creatorship. However, it may involve an extension of existing rights to be involved in decision-making about the management of records, their access and use. And, in some circumstances, might warrant inclusion of ownership rights for all parties to the transaction documented in the records.

\section{Related archival action agenda: refiguring the archive}

- Australian archival profession and institutions to adopt a participant model that involves repositioning record subjects as records agents-participants in the act of records creation (in a fully implemented participant model, every contributor, including the person who is the subject of the document, has legal and moral rights and responsibilities in relation to ownership, access and privacy)

- Expand the definition of record creators in archival science to include everyone who has contributed to a record's creative process and has been affected by its action, thus supporting the enforcement of a broader spectrum of rights and obligations.

\section{Conclusion}

In the context of the guide to implementing the 2007 UN Declaration of the Rights of Indigenous Peoples in Australia, issued by the Australian Human Rights Commission, this Position Statement on Archives and Indigenous Human Rights in Australia and its action agenda provide a road map for realising Indigenous cultural rights in records and archives by the Australian archival community working in partnership with Aboriginal and Torres Strait Islander peoples.

\section{References}

Anderson J (2010) Indigenous/traditional knowledge \& IP issues paper. Prepared for Center for the Study of the Public Domain, Duke University School of Law December 10, 2010 Durham, North Carolina http://www.law.duke.edu/cspd/pdf/ip_indigenous-traditionalknowledge.pdf (Accessed 3 Oct 2011)

ATSILIRN (2005) ATSI Library and Information Resources Network protocols, updated version of 1995 ATSI protocols for libraries, archives and information services www1.aiatsis.gov.au/atsilirn/ home/index.html (Accessed 10 December 2011)

Australian Heritage Commission (2002) Ask first: A guide to respecting Indigenous heritage places and values. Australian Heritage Commission, Canberra http://www.environment.gov.au/heritage/ahc/ publications/commission/books/pubs/ask-first.pdf (Accessed 10 December 2011)

Australian Human Rights Commission (2010) The community guide to the UN Declaration on the Rights of Indigenous Peoples. Canberra: AHRC http://www.humanrights.gov.au/declaration_indigenous/ downloads/declaration_guide2010.pdf (Accessed 10 December 2011)

Australian Institute of Aboriginal and Torres Strait Islander Studies (AIATSIS) (2010) Guidelines for ethical research in Indigenous studies http://www.aiatsis.gov.au/research/docs/ethics.pdf (Accessed 10 December 2011) 
Australian Society of Archivists (1996) Policy statement on archival services and Aboriginal and Torres Strait Islander peoples http://www.archivists.org.au/sitebuilder/about/knowledge/asset/files/4/policy statementonarchivalservice\&a\&tsipeoples.pdf (Accessed 10 December 2011)

Bowrey K, Anderson J (2009) The politics of global information sharing: Whose cultural agendas are being advanced? Soc Legal Stud 8(4):479-504

Calma, Tom (2009) Indigenous issues in the Durban Review. Castan Centre Public Forum, Can the UN combat racism? A preview of the Durban Review Melbourne, 20 February 2009 http://www.law. monash.edu.au/castancentre/events/2009/calma-paper.pdf (Accessed 10 December 2011)

Commonwealth of Australia (1975) Racial Discrimination Act 1975 (Cth) http://www.austlii.edu.au/au/ legis/cth/consol_act/rda1975202/index.html (Accessed 10 December 2011)

Douglas, Jennifer (2010), Origins: evolving ideas about the principle of provenance. In: Terry Eastwood and Heather MacNeil (ed), Currents of archival thinking, Libraries Unlimited, Santa Barbara, Denver, Oxford, pp 23-43

First Archivists Circle (2007) Protocols for native American archival materials (accessed 10 December 2011) http://www2.nau.edu/libnap-p/protocols.html

Fourmile H (1989) Who owns the past?-Aborigines as captives of the archives. Aboriginal History 13:1-2

Iacovino Livia (2010) Rethinking archival, ethical and legal frameworks for records of Indigenous Australian communities: a participant relationship model of rights and responsibilities. Arch Sci 10:353-372

Janke T (1998a) Our culture: our future. Report on Australian Indigenous cultural and intellectual property rights. Michael Frankel and Company, Sydney http://www.terrijanke.com.au/img/publi cations/pdf/24.culture.pdf (Accessed 8 Oct 2011)

Janke T (1998b) Our culture: our future-Report on Australian indigenous cultural and intellectual property rights, Michael Frankel and Company, Sydney (accessed 10 December 2011). http://www. frankellawyers.com.au/media/report/culture.pdf

McKemmish S, Iacovino L, Ketelaar E, Castan M, Russell L (2011) Resetting relationships: archives and Indigenous human rights in Australia. Arch Manuscr 39(1):107-144

Monash University Centre for Organisational and Social Informatics and Centre for Australian Indigenous Studies, the Public Record Office of Victoria, the Koorie Heritage Trust Inc., the Victorian Koorie Records Taskforce, and the Australian Society of Archivists Indigenous Issues Special Interest Group (2009) Trust and technology: building archival systems for Indigenous oral memory. Final report of the Australian Research Council Project. http://www.infotech.monash.edu. $\mathrm{au} /$ research/centres/cosi/projects/trust/final-report/ (Accessed 10 December 2011)

Monash University and the National Archives of Australia (2010) Archives and Indigenous human rights: towards an understanding of the archival and recordkeeping implications of Australian and international human rights for Indigenous Australians. Interdisciplinary Workshop, 12 October 2010 sponsored by the Monash CASTAN Centre for Human Rights, the Centre for Organisational and Social Informatics and Centre for Australian Indigenous Studies and the National Archives of Australia, Australian Society of Archivists Inc. Annual Conference http://infotech.monash.edu.au/ non-cms/about/news/conferences/aihr/ (Accessed 3 Oct 2011)

National and State Libraries Australasia (2007) National policy framework for Aboriginal and Torres Strait Islander library services and collections. 19 September 2006. NSLA http://www.nsla.org.au/ publications/policies (Accessed 10 December 2011)

Nesmith Tom (1999) Still fuzzy, but more accurate: Some thoughts on the "ghosts" of archival theory. Archivaria 47:137-149

Poster Mark (2001) What's the matter with the Internet? University of Minnesota Press, Minneapolis

SLSA, State Library of South Australia (2010) Indigenous protocols and policy: Digital repatriation policy http://www.slsa.sa.gov.au/site/page.cfm?u=243 (Accessed 10 December 2011)

SRNSW, State Records New South Wales (2008) Protocols for staff working with Indigenous people, http://www.records.nsw.gov.au/state-archives/resources-for/indigenous-people/files/Protocols $\% 20$ for $\% 20$ Staff\%20Working\%20with\%20Indigenous\%20People.pdf/view (Accessed 10 December 2011)

UN (1948) United Nations Universal Declaration of Human Rights www.un.org/en/documents/udhr/ index.html (Accessed 10 December 2011)

UN (1965) Convention on the Elimination of Racial Discrimination ("CERD”) 1965 http://www2. ohchr.org/english/law/pdf/cerd.pdf (Accessed 10 December 2011) 
UN (1966a) International Covenant on Civil and Political Rights (ICCPR) 1966 http://www2.ohchr. org/english/law/pdf/ccpr.pdf (Accessed 10 December 2011)

UN (1966b) International Covenant on Economic, Social and Cultural Rights (ICESCR) 1966 http://www2.ohchr.org/english/law/pdf/cescr.pdf (Accessed 10 December 2011)

UN (2007), United Nations General Assembly Declaration on the Rights of Indigenous Peoples http://www.un.org/esa/socdev/unpfii/documents/DRIPS_en.pdf (Accessed 10 December 2011)

UNHRC (1997 \& 2005) United Nations Human Rights Council, Updated set of principles for the protection and promotion of human rights through action to combat impunity (Joinet-Orentlicher Principles) http://www.derechos.org/nizkor/impu/principles.html (Accessed 10 December 2011)

\section{Author Biographies}

Professor Sue McKemmish, Chair of Archival Systems and Director of the Centre for Organisational and Social Informatics at Monash University, is engaged in major research and standards initiatives relating to the use of metadata in records and archival systems, information resource discovery and smart information portals; Australian Indigenous archives; and the development of more inclusive archival research and educational programs that meet the needs of diverse communities.

Dr Livia Iacovino, an Adjunct Senior Research Fellow with the Centre for Organisational and Social Informatics at Monash University, has taught legal and ethical curricula in recordkeeping courses at Monash. Her research and publications are focused on interdisciplinary perspectives of archival science, law and ethics, in particular online rights and responsibilities of ownership, access and privacy in government, health and community contexts.

Professor Lynette Russell has worked and researched in the area of Australian Indigenous Studies for the past 15 years. Lynette is the Director of the Monash Indigenous Centre. She is a Fellow of the Australian Institute of Aboriginal and Torres Strait Islander Studies, Royal Anthropological Institute, and Clare Hall, Cambridge University, and was appointed as Director of the Collections Council of Australia by the Federal Minister for Arts.

Ms Melissa Castan, a Deputy Director of Castan Centre for Human Rights Law and Senior Lecturer in the Faculty of Law, Monash University, teaches and researches in the areas of Indigenous legal rights, Australian constitutional law and human rights generally. Melissa is currently researching issues surrounding Indigenous cultural rights and their protection in international and Australian law. 